JURNAL RISET PENDIDIKAN MATEMATIKA

Volume 3 - Number 2, November 2016, (221 - 233)

Available online at http://journal.uny.ac.id/index.php/jrpm

\title{
KEEFEKTIFAN PROBLEM SOLVING DAN GUIDED INQUIRY DALAM SETTING TAI DITINJAU DARI PRESTASI BELAJAR, KEMAMPUAN BERPIKIR KRITIS, DAN KEDISIPLINAN DIRI
}

\author{
Hesti Setianingsih \\ SMP Negeri 1 Lebaksiu, Jalan Kauman II, Lebaksiu Lor, Lebaksiu, Tegal, 52461, Indonesia \\ Korespondensi Penulis. Email: hestisetianingsih492@yahoo.co.id \\ Received: $21^{\text {th }}$ October 2015; Revised:19 $9^{\text {rd }}$ September 2016; Accepted: $6^{\text {th }}$ October 2016
}

\begin{abstract}
Abstrak
Penelitian ini bertujuan untuk mendeskripsikan keefektifan dan membandingkan keefektifan problem solving setting team assisted individualization (TAI) dengan guided inquirysetting TAI ditinjau dari prestasi belajar, kemampuan berpikir kritis, dan kedisiplinan diri siswa. Populasi penelitian ini adalah seluruh siswa kelas VII SMP Negeri 1 Lebaksiu yang terdiri atas 9 kelas. Dari populasi yang ada diambil secara acak dua kelas, yaitu kelas VII H dan kelas VII I sebagai sampel kelas penelitian. Kelas VII $\mathrm{H}$ diberi treatment dengan pendekatan pembelajaran problem solving setting TAI, sedangkan kelas VII I dengan guided inquiry setting TAI. Data dianalisis dengan menggunakan uji one sample t-test, uji MANOVA dengan $\mathrm{T}^{2}$ Hotteling's dilanjutkan dengan uji $t$ Benferroni untuk menentukan pendekatan pembelajaran mana yang lebih efektif. Hasil penelitian menunjukkan bahwa pendekatan pembelajaran problem solving setting TAI dan guided inquiry setting TAI keduanya efektif ditinjau dari prestasi belajar, kemampuan berpikir kritis, dan kedisiplinan diri; pendekatan pembelajaran guided inquiry setting TAIlebih efektif daripada problem solving setting TAI ditinjau dari masing-masing aspek.
\end{abstract}

Kata Kunci: problem solving, guided inquiry, team assisted individualization, prestasi belajar, kemampuan berpikir kritis, kedisiplinan diri

\section{THE EFFECTIVENESS OF PROBLEM SOLVING AND GUIDED INQUIRY VIEWED FROM STUDENTS' LEARNING ACHIEVEMENT, CRITICAL THINKING SKILLS, AND SELF-DISCIPLINE}

\begin{abstract}
This study aims to describe the effectiveness and compare the effectiveness of problem solving in team assisted individualization (TAI) setting with guided inquiry in TAI setting viewed from the students' learning achievement, critical thinking skills, and self-discipline. The research population comprised all Class VII students, consisting of 9 classes of SMP Negeri 1 Lebaksiu. From the population, two groups (classes), class VII H and class VII I, were selected randomly as the research class sample. Class VII H was treated with the approach of learning problem solving in TAI setting, while class VII I was treated with the guided inquiry in TAI setting. The data were analyzed using one sample t-test, MANOVA with $T^{2}$ Hotteling's and then continued by t-Benferroni test to determine which the approach of learning is more effective. The results of study show that the approaches of learning problem solving in TAI setting and guided inquiry in TAI setting are both effective viewed from students' learning achievement, critical thinking skills, and self-discipline, and the approach of learning guided inquiry in TAI setting is more effective than problem solving in TAI setting in terms of each aspect.
\end{abstract}

Keywords: problem solving, guided inquiry, team assisted individualization, learning achievement, critical thinking skills, self-discipline

How to Cite: Setianingsih, H. (2016). Keefektifan problem solving dan guided inquiry dalam setting TAI ditinjau dari prestasi belajar, kemampuan berpikir kritis, dan kedisiplinan diri. Jurnal Riset Pendidikan Matematika, 3(2), 221-233. doi:http://dx.doi.org/10.21831/jrpm.v3i2.6143

Permalink/DOI: http://dx.doi.org/10.21831/jrpm.v3i2.6143 


\section{PENDAHULUAN}

Pertumbuhan penduduk, perkembangan ilmu pengetahuan dan teknologi yang pesat di abad XXI memberikan dampak sekaligus tantangan terhadap dunia pendidikan, termasuk adanya ekspansi perusahaan-perusahaan ke pasar bebas dan pasar global. Hal ini menyebabkan orang-orang di seluruh dunia bersaing dalam mencarikan sekolah yang berkualitas bagi anaknya, mendapatkan uang maupun pekerjaan, baik antarwarga negara pribumi maupun antarwarga negara asing. Untuk menghadapi tantangan tersebut, dituntut sumber daya manusia handal dan mampu berkompetisi secara global, yang memerlukan keterampilan tinggi yang didasari pemikiran kritis, sistematis, logis, kreatif dan kemampuan bekerja sama yang efektif.

Dalam Paradigma Pendidikan Nasional Abad XXI berdasarkan " $21^{s t}$ Century Partnership Learning Framework" (BNSP, 2010, p.44), salah satu kompetensi yang harus dimiliki oleh sumber daya manusia (SDM) abad XXI adalah kemampuan berpikir kritis dan pemecahan masalah. Selain kedua kompetensi, tersebut dalam abad XXI diperlukan pula SDM yang memiliki karakter leadership, personal responsibility, ethics, people skills, adaptability, selfdirection, accountability, social responsibility, personal productivity (BNSP, 2010, p.45). Menyadari akan tingginya tuntutan SDM, maka sistem serta model pendidikan harus mengalami transformasi, seperti pemanfaatan teknologi pendidikan dalam tukar menukar pengetahuan dan kolaborasi antar siswa-siswa dan guru-guru di seluruh dunia, guru berfungsi sebagai fasilitator, memperbanyak interaksi siswa dengan lingkungan sekitar, penggunaan metode belajar mengajar kreatif dan materi ajar yang kontekstual. Selain itu diperlukan pula suatu program pendidikan yang dapat mengembang-kan kemampuan berpikir kritis, sistematis, logis dan kreatif. Salah satu program pendidikan tersebut adalah program pembelajaran matematika.

Melihat pentingnya program pembelajaran matematika dan peranan-matematika dalam menghadapi kemajuan ilmu pengetahuan dan teknologi maka peningkatan mutu pendidikan dan atau pembelajaran matematika di semua jenis dan jenjang pendidikan harus selalu diupayakan. Salah satunya dengan diberlakukannya Kurikulum Tingkat Satuan Pendidikan (KTSP).
Dalam Peraturan Menteri Pendidikan Nasional Nomor 23 Tahun 2006 tentang Standar Kompetensi Lulusan (SKL) Mata Pelajaran Sekolah Menengah Pertama (SMP)/Madrasah Tsanawiyah (MTs) menyebutkan bahwa salah satu kompetensi yang harus dimiliki oleh siswa setelah mempelajari matematika yaitu memiliki kemampuan berpikir logis, analitis, kritis, dan kreatif serta mempunyai kemampuan bekerja sama. Salah satu keterampilan yang harus dimiliki siswa adalah kemampuan berpikir kritis. Hal ini karena kemampuan berpikir kritis akan membantu siswa dalam pengambilan keputusan yang masuk akal dalam hidupnya. Berpikir kritis penting bagi setiap orang, sebagaimana pendapat Rudinow \& Barry (2008, p.6) bahwa berpikir kritis merupakan kemampuan yang dapat meningkatkan peluang keberhasilan seseorang dalam hubungan atau karir, kemampuan sebagai konsumen potensial produk dan jasa, kemampuan sebagai warga negara dan anggota masyarakat yang memungkinkan berperan dalam berbagai peran sosial.

Secara teori, kemampuan berpikir kritis menurut Haryani (2012, p.146) diartikan sebagai kemampuan siswa dalam membuat keputusan yang masuk akal mengenai apa yang dipercayai atau dilakukan. Akan tetapi, fakta menunjukkan hasil yang tidak sesuai dengan yang diharapkan mengenai kemampuan berpikir kritis. Hal tersebut didukung hasil penelitian Priatna (2003) yang menunjukkan bahwa kemampuan penalaran dan pemahaman matematika siswa SMP di kota Bandung belum memuaskan, yaitu hanya mencapai sekitar $49 \%$ dan $50 \%$ dari skor ideal yaitu 60 dan 58. Begitu pula dengan hasil penelitian Mayadiana (2005) menunjukkan kemampuan berpikir kritis mahasiswa calon guru sekolah dasar masih rendah, yakni hanya mencapai $36,26 \%$ untuk mahasiswa berlatar belakang IPA, $26,62 \%$ untuk mahasiswa berlatar belakang Non-IPA, serta 34,06\% untuk keseluruhan mahasiswa dari skor maksimum 60.

Kedua hasil penelitian tersebut sebagai gambaran bahwa siswa mengalami masalah dalam hal rendahnya kemampuan berpikir kritis.

Kemampuan berpikir kritis dapat dikembangkan melalui kegiatan pembelajaran di kelas. Trilling \& Fadel (2009, p.53) menyatakan bahwa kemampuan berpikir kritis dan pemecahan masalah dapat dipelajari melalui berbagai program kegiatan penyelidikan dan kegiatan pemecahan masalah. Kedua kemampuan tersebut dikembangkan secara efektif melalui proyek- 
proyek pembelajaran bermakna dengan melibatkan pertanyaan dan masalah.

Potensi yang dimiliki siswa bisa berkembang secara aktif melalui pendidikan. Untuk mengembangkan potensi siswa adalah dengan membentuk suasana belajar dan proses pembelajaran yang baik untuk semua jenjang pendidikan (Undang-Undang, 2003) sehingga tujuan pembelajaran yang dirumuskan dalam indikator pencapaian kompetensi dapat dicapai, termasuk dalam matematika. Hal tersebut kemudian berhubungan dengan prestasi belajar matematika siswa. Untuk melihat baik atau tidaknya prestasi belajar matematika siswa dilakukan dengan cara melihat apakah indikator pencapaian kompetensi tersebut sudah tercapai oleh siswa atau tidak. Prestasi belajar matematika diartikan Muslimin (2012, p.382) sebagai hasil yang diperoleh siswa selama pembelajaran matematika berlangsung dalam jangka waktu tertentu yang dinyatakan dalam bentuk nilai.

Terkait pentingnya prestasi belajar matematika, menurut Lovat, et al (2011, p.6) "since the early 1990s, there has been a concentration of effort aimed at maximizing student achievement in school education". Harapan ini tidak sejalan dengan fakta yang terjadi, sebagaimana diungkapkan Dehya-degary, et al (2012, p.823) "one of the vast crises of the educational system in many countries, especially third world countries is the problem of low academic achievement". Hal ini sejalan dengan fakta yang terjadi di Indonesia terkait materi geometri. Berdasarkan data BSNP mengenai laporan hasil ujian nasional (UN) dua tahun terakhir, tahun pelajaran 2011/2012, 2012/2013 diperoleh hasil bahwa nilai UN Sekolah Menengah Pertama (SMP) di Indonesia untuk materi tersebutmasih terletak di bawah kriteria ketuntasan minimal (KKM) yang biasanya ditetapkan sekolah, yaitu sebesar $70 \%$. Hal tersebut menjadi masalah di SMP Negeri 1 Lebaksiu karena persentase penguasaan materi geometri masih rendah yang disajikan dalam Tabel 1.

Selain penguasaan materi geometri kelas IX yang masih rendah, hasil ulangan akhir semester (UAS) mata pelajaran matematika kelas VII pun menunjukkan hal yang relatif sama. Rata-rata hasil UAS dua tahun terakhir adalah 65,98 dan 53,07. Proses pembelajaran matematika di kelas yang selama ini terjadi belum sesuai dengan yang diharapkan. Pada kenyataannya siswa sulit untuk menguasai kompetensi-kompetensi berpikir logis, kritis, kreatif, inovatif, dan penalaran apabila guru menerapkan metode yang kurang bervariasi. Setiap siswa bisa saja memiliki kemampuan baik dalam suatu materi, tetapi ketika dihadapkan pada soal nonrutin, siswa mengalami kesulitan dan menyerah sebelum mencoba menyelesaikan soal tersebut. Hal ini terjadi karena sebagian siswa masih menganggap matematika sebagai mata pelajaran yang menakutkan, sulit dipahami, membosankan bahkan dijauhi. Hal tersebut ditegaskan oleh pendapat Muijs \& Reynold (2005, p.212) yang menyatakan "mathematics is commonlyseen as one of the most difficult subject by pupils and adults like". Selain itu, salah satu penyebab rendahnya prestasi belajar matematika siswa (McKinley, 2010, p.2) adalah "poor interpersonal relationship" atau rendahnya hubungan antarindividu. Hal ini mengindikasikan bahwa pembelajaran di kelas sebaiknya memberikan kesempatan kepada siswa untuk saling berinteraksi, salah satunya dengan pemberian tugas-tugas yang bersifat kelompok.

Tabel 1. Persentase Penguasaan Materi Geometri SMP Negeri 1 Lebaksiu

\begin{tabular}{lcc}
\hline \multicolumn{1}{c}{ Kemampuan yang Diuji } & $\begin{array}{c}\mathbf{2 0 1 1} / \\
\mathbf{2 0 1 2}\end{array}$ & $\begin{array}{c}\mathbf{2 0 1 2} / \\
\mathbf{2 0 1 3}\end{array}$ \\
\hline $\begin{array}{l}\text { Menyelesaikan masalah yang } \\
\text { berkaitan dengan luas bangun } \\
\text { datar }\end{array}$ & 24,18 & 33,89 \\
$\begin{array}{l}\text { Menyelesaikan masalah yang } \\
\text { berkaitan dengan garis-garis }\end{array}$ & 66,67 & 46,84 \\
$\begin{array}{l}\text { istimewa pada segitiga } \\
\text { Menyelesaikan masalah yang } \\
\text { berkaitan dengan keliling bangun } \\
\text { datar }\end{array}$ & 83,33 & 62,79 \\
$\begin{array}{l}\text { Menyelesaikan masalah yang } \\
\text { berkaitan dengan luas permukaan } \\
\text { bangun ruang }\end{array}$ & 57,36 & 42,42 \\
$\begin{array}{l}\text { Menyelesaikan masalah yang } \\
\text { berkaitan dengan volume bangun } \\
\text { ruang }\end{array}$ & 74,02 & 45,35 \\
\hline
\end{tabular}

Selain data tersebut, berdasarkan pengamatan di SMP Negeri 1 Lebaksiu ditemukan beberapa hal berkaitan dengan pembelajaran diantaranya dominasi guru dalam pembelajaran besar, siswa kurang aktif di kelas, siswa tidak sering bertanya padahal siswa tidak bisa atau kurang mengerti, siswa kurang konsentrasi dalam pembelajaran matematika, siswa lebih fokus menghafal konsep dan rumus tanpa diimbangi dengan pemahaman, siswa mudah menyerah ketika diberikan soal nonrutin, frekuensi pemberian soal pemecahan masalah dan penalaran yang rendah, pengerjaan tugas yang tidak berhubungan dengan pembelajaran yang sedang berlangsung, tidak mengerjakan tugas maupun 
pekerjaan rumah, pengerjaan dan pengumpulan tugas tidak sesuai target waktu, bolos dalam pembelajaran, bolos dari sekolah, datang terlambat masuk sekolah, dan seragam dengan atribut yang tidak sesuai tata tertib sekolah.

Menurut McElmeel (2002, p.185) bahwa disiplin diri merupakan kemampuan untuk mengendalikan, mengelola, atau mengoreksi diri demi perbaikan. Pusat pengendalinya ada di dalam dirinya sendiri (Gordon, 1996, p.8). Oleh karena itu, diperlukan pembelajaran yang dapat menumbuhkan sikap dan perilaku positif dan tanggung jawab, sebagaimana pendapat yang disampaikan oleh Savage \& Savage (2010, p.8) bahwa disiplin akan memfasilitasi pengembangan kontrol diri, tanggung jawab dan karakter. Begitu pula dengan pendapat Johnson (2003, p.10) bahwa sikap dan berbicara positif pada diri sendiri akan meningkatkan ketangguhan mental dan disiplin diri.

Berdasarkan data dari TIMSS \& PIRLS International Study Center (2012, p.42) bahwa Indonesia dengan rata-rata 386 menempati peringkat 38 dari 45 negara peserta TIMSS pada tahun 2011. Domain kognitif TIMSS adalah pengetahuan, penerapan dan penalaran, sedangkan domain kontennya adalah bilangan, aljabar, geometri, serta data dan peluang. Siswa-siswa Indonesia hanya mampu pada Low, Intermediate International Benchmark. Persentase siswa yang mencapai High Internasional Benchmark hanya 2\%, sedangkan untuk Advanced International Benchmark tidak ada (TIMSS \& PIRLS International Study Center, 2012, p.118).

Indikator High International Benchmark pada bagian geometri adalah dapat menggunakan sifat garis, sudut, segitiga, persegi panjang dan prisma segiempat untuk memecahkan masalah,sementara untuk Advanced Internasional Benchmark dapat memberikan alasan dengan menggunakan gambar geometri untuk memecahkan masalah (TIMSS \& PIRLS International Study Center, 2012, p.13). Berdasarkan data tersebut menunjukkan bahwa rendahnya kemampuan penalaran termasuk kemampuan berpikir kritis dan pemecahan masalah siswasiswa Indonesia. Hal tersebut karena penalaran menurut Krulik \& Rudnick (Happy \& Widjajanti, 2014, p.49) mencakup berpikir dasar (basic thinking), berpikir kritis (critical thinking), dan berpikir kreatif (creative thinking).

IMSTEP-JICA (Herman, 2007, p.42) dan McKinley (2010, p.2) mengungkapkan bahwa penyebab utama rendahnya prestasi belajar matematika, kemampuan berpikir kritis dan sikap siswa terhadap proses pembelajaran matematika adalah kurangnya interaksi atau keterlibatan siswa secara langsung dalam pembelajaran. Hal ini disebabkan karena pembelajaran matematika di kelas cenderung berpusat pada guru. Berdasarkan atas hal ini, maka menerapkan pendekatan pembelajaran yang melibatkan siswa secara langsung dalam pembelajaran diduga dapat menjadi solusi dari masalah tersebut. Selain itu, disebutkan juga bahwa pembelajaran yang memperhatikan pengetahuan prasyarat siswa dan mengelompokkan siswa dalam kelompok-kelompok kecil merupakan solusi yang tepat untuk mengembangkan prestasi belajar matematika dan sikap siswa terhadap proses pembelajaran matematika (Brownlie, et al, 2003, pp.12-13).

Pendekatan problem solving merupakan pendekatan pembelajaran yang terpusat pada siswa dan menitikberatkan pada pemberian masalah oleh guru kepada siswa untuk memperoleh konsep matematika yang terkandung dalam proses pemecahan masalah tersebut. Adapun langkah-langkah pembelajaran dengan menggunakan pendekatan ini adalah memahami masalah, membuat rencana, melaksanakan rencana, dan melihat kembali (Polya, 1985, p.5-19).

Keunggulan pendekatan problem solving, yaitu dapat mengembangkan sikap positif siswa terhadap proses pembelajaran matematika (Haylock \& Thangata, 2007, pp.147-148). Keunggulan pendekatan problem solving juga didukung oleh hasil penelitian Jalal (2012) yang menyimpulkan pendekatan pemecahan masalah model polya efektif ditinjau dari kemampuan penalaran, berpikir kritis, dan berpikir kreatif matematik siswa. Hasil penelitian Mustamil (2012) juga menyimpulkan bahwa pendekatan problem solving mampu meningkatkan prestasi belajar matematika siswa. Begitu pula dengan hasil penelitian Junaidi (2012) menyimpulkan bahwa penerapan pendekatan problem solving pada pembelajaran matematika di kelas X SMA mampu mengembangkan sikap positif siswa terhadap proses pembelajaran matematika.

Guided inquiry merupakan salah satu tipe dari inkuiri. Inkuiri merupakan pendekatan pembelajaran dimana siswa menemukan dan menggunakan berbagai sumber informasi dan ide-ide untuk meningkatkan pemahamannya tentang masalah, topik atau isu-isu (Kuhlthau, et al, 2007, p.2). Inkuiri tidak sekedar untuk menjawab pertanyaan atau mendapatkan jawaban tetapi memerlukan investigasi yang akan menarik dan menantang bagi siswa, melibatkan 
interaksi sosial dan membutuhkan bimbingan dari guru (Kuhlthau, et al, 2007, p.2). Adapun langkah-langkah pembelajaran dengan menggunakan pendekatan ini adalah mengidentifikasi masalah, mengumpulkan data, memilah data, analisis data dan mengevaluasi.

Salah satu keunggulan dari pembelajaran inkuiri adalah dapat membangun kemampuan mental meneliti dan memproses informasi (Bell, 1978, p.342). Selanjutnya Marzano (Markaban, 2006, p.18) menambahkan kelebihan dari guided inquiry diantaranya adalah siswa dapat berpartisipasi aktif dalam pembelajaran yang disajikan, menumbuhkan sekaligus menanamkan sikap inkuiri, materi yang dipelajari dapat mencapai tingkat kemampuan tinggi dan lebih lama membekas karena siswa dilibatkan dalam proses menemukannya. Trowbridge \& Bybee (1986, p.183) menambahkan bahwa selain membangun kemampuan kognitif, pembelajaran inkuiri juga dapat membangun kemampuan psikomotorik serta kemampuan afektif seperti objektif, rasa ingin tahu, pikiran terbuka, menghargai model teori, bertanggungjawab, menunda keputusan sampai memperoleh data yang cukup, melihat kembali hasil.

Pendekatan problem solvingdanguided inquirymenitikberatkan pada pemberian masalah dimana masalah yang diberikan mungkin dianggap sulit atau bahkan tidak bisa diselesaikan sendiri oleh beberapa siswa. Akan tetapi bantuan dan masukan dari teman sebaya akan memudahkan siswa untuk menyelesaikan masalah tersebut sehingga setting kooperatif diperlukan dalam penerapan pendekatan ini.

Penggunaan setting pembelajaran kooperatif tipe TAI dalam pendekatan problem solvingdanguided inquirymemungkinkan siswa selalu terlibat aktif dalam proses belajar, karena siswa mempunyai tanggung jawab belajar yang lebih besar. Tanggung jawab belajar ini dapat terbentuk salah satunya dikarenakan adanya struktur tugas dan struktur penghargaan dalam pembelajaran kooperatif. Struktur tugas dalam TAI memungkinkan siswa untuk saling bekerja sama untuk mencapai tujuan bersama. Dalam pembelajaran kooperatif, siswa akan mencapai tujuan apabila siswa yang lain juga mencapai tujuan tersebut. Hal ini berarti bahwa tujuan akan dicapai apabila seluruh anggota kelompok ikut andil untuk mencapai tujuan sehingga akan menimbulkan ketergantungan positif antaranggota kelompok. Tiap anggota kelompok memiliki kontribusi tersendiri untuk melakukan usaha bersama. Dengan adanya ketergantungan positif antaranggota ini setiap siswa berusaha untuk mencapai tujuan pembelajaran yang ditetapkan.

Penggunaansetting pembelajaran kooperatif tipe TAI dalam pendekatan problem solving dan guided inquiry didukung oleh penelitian Gok \& Silay (2010) yang dilakukan terhadap siswa kelas 10 di Turkey dimana hasilnya menunjukkan problem solving lebih efektif daripada pembelajaran konvensional ditinjau dari aspek prestasi belajar siswa. Begitu pula hasil penelitian Bilgin (2009) yang dilakukan terhadap 55 mahasiswa Mustafa Kemal University menunjukkan bahwa pembelajaran guided inquiry setting pembelajaran kooperatif, mahasiswa memiliki pemahaman yang lebih baik dan sikap yang lebih positif daripada menggunakan pembelajaran guided inquiry.

Berdasarkan uraian tersebut rumusan masalah dari penelitian ini adalah, (1) Apakah problem solvingsetting TAI dan guided inquiry setting TAI pada pembelajaran geometri efektif ditinjau dari prestasi belajar, kemampuan berpikir kritis, dan kedisiplinan diri siswa?; (2) Manakah yang lebih efektif antara problem solving setting TAI denganguided inquiry setting TAI pada pembelajaran geometri ditinjau dari prestasi belajar, kemampuan berpikir kritis, dan kedisiplinan diri siswa?

Sesuai dengan rumusan masalah tersebut, maka tujuan penelitian ini adalah untuk mendeskripsikan: (1) keefektifan problem solving setting TAIdan guided inquiry setting TAI pada pembelajaran geometri ditinjau dari prestasi belajar, kemampuan berpikir kritis, dan kedisiplinan diri siswa; (2) perbandingan keefektifan problem solvingsetting TAI dan guided inquiry setting TAI pada pembelajaran geometri ditinjau dari prestasi belajar, kemampuan berpikir kritis, dan kedisiplinan diri siswa.

Manfaat dari penelitian ini secara teori dapat memberikan sumbangan dalam pembelajaran matematika yang berkaitan dengan problem solving setting TAI, guided inquiry setting TAI dan bagaimana keefektifan kedua pendekatan pembelajaran tersebut pada pembelajaran geometri ditinjau dari aspek prestasi belajar, kemampuan berpikir kritis, dan kedisiplinan diri siswa. Sedangkan secara praktis dimanfaatkan sebagai bahan pertimbangan dalam memilih pendekatan pembelajaran yang tepat, terutama jika ingin meningkatkan prestasi belajar, kemampuan berpikir kritis, dan kedisiplinan diri siswa. 


\section{Jurnal Riset Pendidikan Matematika, 3 (2), November 2016 - 226}

Hesti Setianingsih

\section{METODE}

Jenis penelitian ini adalah quasi experiment. Adapun desain yang digunakan adalah pretest-posttest nonequivalent comparisongroup design. Group (kelompok) yang digunakan dalam penelitian ini terdiri atas dua kelompok. Dua kelompok ini kemudian diberikan treatment berupa menerapkan pembelajaran dengan menggunakan problem solving setting TAI (kelompok pertama) dan guided inquirysetting TAI (kelompok kedua).

Penelitian ini dilaksanakan di SMP Negeri 1 Lebaksiu Kabupaten Tegal Provinsi Jawa Tengah pada tanggal 23 Maret sampai dengan 8 Mei 2015.

Populasi dari penelitian ini adalah seluruh siswa kelas VII SMP Negeri 1 Lebaksiu Kabupaten Tegal Tahun Pelajaran 2014/2015 yang berada dalam sembilan kelas. Dalam penelitian ini dipilih dua kelas secara acak sebagai sampel. Kelompok kelas yang terpilih adalah kelas VII $\mathrm{H}$ dan VII I. Selanjutnya secara acak terpilih kelas VII H sebagai kelompok yang diberikan treatment pembelajaran dengan menggunakan problem solving setting TAI dan kelas VII I sebagai kelompok yang diberikan treatment pembelajaran dengan menggunakan guided inquirysetting TAI.

Desain penelitian yang digunakan adalah pretest-posttest nonequivalent comparisongroup design. Siswa kedua kelas diberikan tes prestasi belajar, kemampuan berpikir kritis, dan angket kedisiplinan diri siswa baik sebelum maupun setelah treatment.

\section{Data, Intrumen, dan Teknik Pengumpulan Data}

Jenis data dalam penelitian ini adalah data kuantitatif yang diperoleh dari data hasil tes prestasi belajar, tes kemampuan berpikir kritis, dan angket kedisiplinan diri.Untuk instrumen yang digunakan dalam penelitian ini adalah tes prestasi belajar, tes kemampuan berpikir kritis, dan angket kedisiplinan diri.

Pengumpulan data untuk instrumen tes mengenai prestasi belajar diperoleh dengan menggunakan tes berupa tes pilihan ganda sebanyak 30 butir dan data kemampuan berpikir kritis diperoleh dengan menggunakan tes berupa tes uraian sebanyak 5 butir.Pemberian tes soal pilihan ganda dan uraian tersebut diberikan kepada kedua kelas baik sebelum maupun setelah treatment. Sedangkan data untuk instrumen nontes mengenai kedisiplinan diri siswa diper- oleh dengan menggunakan angket yang berbentuk checklist dengan skala Likert.Angket kedisiplinan diri siswa terdiri atas 30 butir. Tiga belas butir pernyataan menggunakan skala Likert dengan lima kategori sangat setuju, setuju, ragu-ragu, tidak setuju, dan sangat tidak setuju. Selanjutnya tujuh belas butir pernyataan berikutnya menggunakan skala Likert dengan kategori selalu, sering, kadang-kadang, jarang, dan tidak pernah.Angket kedisiplinan diri siswa terdiri dari 18 pernyataan positif dan 12 pernyataan negatif. Aspek kedisiplinan diri yaitu pengendalian diri, koreksi diri, dan ketertiban. Pengendalian diri meliputi mampu mengabaikan hal-hal yang tidak penting dan mampu mengontrol diri. Sedangkan koreksi diri meliputi kemampuan mengoreksi diri dan melakukan sesuatu tanpa disuruh. Selanjutnya ketertiban meliputi tertib dan patuh pada aturan.

Teknik pengumpulan data dalam penelitian ini melalui tahapan sebagai berikut: (a) menyusun instrumen penelitian dan bahan ajar penelitian; (b) meminta beberapa dosen untuk memvalidasi instrumen penelitian; (c) uji coba instrumen penelitian; (d) mengajukan perizinan ke sekolah; (e) memberikan tes dan angket sebelum perlakuan pada sampel penelitian; (f) melakukan penelitian berkolaborasi dengan guru; (g) memberikan tes dan angket setelah perlakuan pada sampel penelitian; (h) analisis data.

\section{Teknik Analisis Data}

Analisis deskriptif digunakan untuk mendeskripsikan data hasil penelitian. Analisis deskriptif yang digunakan dalam penelitian ini untuk data prestasi belajar, kemampuan berpikir kritis, dan kedisiplinan diri siswa adalah ratarata, standar deviasi, varians, skor maksimum, dan skor minimum.Data penelitian yang dianalisis adalah data hasil pretest dan posttest pada aspek prestasi belajar, kemampuan berpikir kritis, dan kedisiplinan diri siswa baik sebelum maupun setelah treatment.

Data prestasi belajar yang diperoleh melalui pengukuran dengan instrumen tes yang berbentuk pilihan ganda dikonversi sehingga menjadi nilai dengan rentang antara skor 0 sampai 100.Skor tersebut kemudian digolongkan dalam kriteria ketuntasan minimal (KKM) yang ditetapkan oleh sekolah untuk pelajaran matematika yaitu minimal 71 .

Data kemampuan berpikir kritis siswa menggunakan tes berbentuk uraian sebanyak 5 soal. Penilaian setiap soal berdasarkan rubrik penskoran kemampuan berpikir kritis siswa 
yang telah ditentukan berdasarkan rubrik penskoran. Skor tersebut kemudian digolongkan dalam KKM yang ditetapkan oleh sekolah untuk pelajaran matematika yaitu minimal 71. Sedangkan skor keefektifan untuk kedisiplinan diri siswa adalah pada kategori B artinya lebih dari 100 pada skala 30 sampai 150 . Untuk setiap pernyataan responden akan diberikan skor sesuai dengan nilai skala kategori jawaban yang diberikannya berdasarkan kategori kedisiplinan diri siswa yang diadaptasi dariAzwar (2013, p.163) sebagai berikut.

Tabel 2. Kriteria Kedisiplinan Diri Siswa

\begin{tabular}{cc}
\hline Interval & Kategori \\
\hline $120<\mathrm{X} \leq 150$ & $\mathrm{~A}$ \\
$100<\mathrm{X} \leq 120$ & $\mathrm{~B}$ \\
$80<\mathrm{X} \leq 100$ & $\mathrm{C}$ \\
$60<\mathrm{X} \leq 80$ & $\mathrm{D}$ \\
$30 \leq \mathrm{X} \leq 60$ & $\mathrm{E}$ \\
\hline
\end{tabular}

Selanjutnya, untuk mengetahui keefektifan dari masing-masing pendekatan pembelajaran yang diterapkan ditinjau dari masing-masing aspek yaitu prestasi belajar, kemampuan berpikir kritis, dan kedisiplinan diri siswa digunakan uji statistikone sample t-test.Secara umum hipotesis statistik yang diuji adalah:

$\mathrm{H}_{0}: \mu \leq \mu_{0}$

$\mathrm{H}_{a}: \mu>\mu_{0}$

Rumus yang digunakan dalam uji one sample t-test adalah sebagai berikut

$t=\frac{\bar{x}-\mu_{0}}{\frac{S}{\sqrt{n}}}$

(Kirk, 1995, p.53)

Keterangan:

$\bar{x}=$ Nilai rata-rata

$\mu_{0}=$ Nilai yang dihipotesiskan

$\mathrm{S}=$ Standar deviasi sampel

$\mathrm{n}=$ Ukuran sampel

Kriteria keputusan yaitu $\mathrm{H}_{0}$ ditolak jika nilai signifikansinya lebih kecil dari 0,05 . Adapun $\mu_{0}$ merupakan rata-rata nilai siswa berdasarkan kriteria ketuntasan minimal yang ditetapkan SMP Negeri 1 Lebaksiu yaitu minimal 71 untuk tes prestasi belajar matematika dan tes kemampuan berpikir kritis, dan rata-rata skor siswa dalam kategori B yaitu lebih dari 100 untuk angket kedisiplinan diri.

Selanjutnya, untuk mengetahui pendekatan pembelajaran yang lebih efektif maka digunakan uji lanjut univariat dengan kriteria
Bonferroni setelah dilakukan uji MANOVA $T^{2}$ Hotelling's. Hipotesis yang akan diuji disimbolkan:

$\begin{aligned} \mathrm{H}_{01}:\left(\begin{array}{l}\mu_{11} \\ \mu_{21} \\ \mu_{31}\end{array}\right) & =\left(\begin{array}{l}\mu_{12} \\ \mu_{22} \\ \mu_{32}\end{array}\right) \\ \mathrm{H}_{\mathrm{a} 1}:\left(\begin{array}{l}\mu_{11} \\ \mu_{21} \\ \mu_{31}\end{array}\right) & \neq\left(\begin{array}{l}\mu_{12} \\ \mu_{22} \\ \mu_{32}\end{array}\right)\end{aligned}$

Keterangan:

$\mu_{11}=$ rerata prestasi belajar dengan menggunakan problem solving setting TAI

$\mu_{12}=$ rerata prestasi belajar dengan menggunakan guided inquiry setting TAI

$\mu_{21}=$ rerata kemampuan berpikir kritis dengan menggunakan problem solving setting TAI

$\mu_{22}=$ rerata kemampuan berpikir kritis dengan menggunakan guided inquiry Setting TAI

$\mu_{31}=$ rerata kedisiplinan diri siswa dengan menggunakan problem solving setting TAI

$\mu_{32}=$ rerata kedisiplinan diri siswa dengan menggunakan guided inquiry Setting TAI

Adapun rumus yang digunakan untuk uji multivariat $T^{2}$ Hotelling's (MANOVA) adalah sebagai berikut:

$$
T^{2}=\frac{n_{1} \cdot n_{2}}{n_{1}+n_{2}}\left(\overline{y_{1}}-\overline{y_{2}}\right)^{\prime} S^{-1}\left(\overline{y_{1}}-\overline{y_{2}}\right)
$$

(Stevens, 2009, p.151)

Keterangan:

$T^{2}=$ Hotelling's Trace

$n_{l}=$ banyak anggota sampel I

$n_{2}=$ banyak anggota sampel II

$\overline{y_{1}}-\overline{y_{2}}=$ mean vektor

$S^{-1}=$ invers matriks kovariansi

Selanjutnya nilai $T^{2}$ Hotteling's ditransformasikan untuk memperoleh nilai distribusi $F$ dengan formula sebagai berikut:

$$
F=\frac{n_{1}+n_{2}-p-1}{\left(n_{1}+n_{2}-2\right) p} T^{2}
$$

dengan $p$ adalah banyaknya variabel terikat. Adapun kriteria pengujiannya adalah $\mathrm{H}_{01}$ ditolak jika nilai signifikansinya lebih kecil dari 0,05 .

Jika pada uji MANOVA diperoleh hasil uji kesamaan rata-rata (mean) skor pada setiap kelompok berbeda signifikan maka uji hipotesis selanjutnya adalah uji univariat $(t)$ dengan menggunakan kriteria Benferroni atau $t$ - 
Benferroni. Hipotesis yang akan diuji adalah sebagai berikut:

$$
\begin{aligned}
& \mathrm{H}_{02}: \mu_{12} \leq \mu_{11} \\
& \mathrm{H}_{\mathrm{a} 2}: \mu_{12}>\mu_{11} \\
& \mathrm{H}_{03}: \mu_{22} \leq \mu_{21} \\
& \mathrm{H}_{\mathrm{a} 3}: \mu_{22}>\mu_{21} \\
& \mathrm{H}_{04}: \mu_{32} \leq \mu_{31} \\
& \mathrm{H}_{\mathrm{a} 4}: \mu_{32}>\mu_{31} \\
& \text { Adapun rumus yang digunakan untuk uji } \\
& \text { univariat }(t) \text { dengan menggunakan kriteria } \\
& \text { Benferroni adalah: } \overline{y_{1}-\overline{y_{2}}} \\
& \quad t=\frac{\sqrt{\frac{\left(n_{1}-1\right) S_{1}^{2}+\left(n_{2}-1\right) S_{2}^{2}}{n_{1}+n_{2}-2}\left(\frac{1}{n_{1}}+\frac{1}{n_{2}}\right)}}{\sqrt{ }}
\end{aligned}
$$

(Stevens, 2009, p.147)

Keterangan:

$\overline{y_{1}}=$ nilai rata-rata sampel I

$\overline{y_{2}}=$ nilai rata-rata sampel II

$S_{1}^{2}=$ varians sampel I

$S_{2}^{2}=$ varians sampel II

$n_{1}=$ banyak anggota sampel I

$n_{2}=$ banyak anggota sampel II

Kriteria pengujian untuk statistik uji tersebut adalah $\mathrm{H}_{0}$ ditolak jika

$t_{h i t} \geq t\left(\frac{\alpha}{p} ; n_{1}+n_{2}-2\right)$.

Sebelum dilakukan uji MANOVA terlebih dahulu harus dipenuhi dua asumsi yaitu uji normalitas multivariat dan uji homogenitas matriks varian-kovarian sebelum dan setelah treatment pada kedua kelompok. Uji normalitas multivariat dilakukan dengan menggunakan Mahalanobis $\left(d_{i}^{2}\right)$. Asumsi normalitas multivariat terpenuhi jika sekitar 50\% data mempunyai nilai $d_{i}^{2}<\chi_{(p ; 0.5)}^{2}$. Untuk uji homogenitas matriks varian-kovarian dilakukan dengan uji homogenitas Box's M dengan kriteria data dikatakan telah memenuhi uji asumsi homogenitas matriks varian-kovarian jika nilai signifikansinya lebih besar dari 0,05 dengan bantuan SPSS 16 for windows.

\section{HASIL DAN PEMBAHASAN}

Deskripsi hasil penelitian merupakan gambaran data yang diperoleh dari penelitian yang dilaksanakan sebanyak sepuluh kali pertemuan, untuk mendukung pembahasan hasil penelitian. Deskripsi masing-masing data sebelum perlakuan dan setelah perlakuan dijelaskan dalam uraian berikut.
Tabel 3. Deskripsi Data Prestasi Belajar Matematika

\begin{tabular}{ccccc}
\hline \multirow{2}{*}{ Deskripsi } & \multicolumn{2}{c}{ PS Setting TAI } & \multicolumn{2}{c}{ GI Seting TAI } \\
\cline { 2 - 5 } & Pre & Post & Pre & Post \\
\hline Rerata & 37,26 & 75,98 & 38,89 & 79,39 \\
Max & 50,00 & 86,67 & 56,67 & 93,33 \\
Min & 20,00 & 60,00 & 20,00 & 66,67 \\
SD & 8,02 & 5,96 & 9,63 & 6,48 \\
Variansi & 64,29 & 35,55 & 92,83 & 41,98 \\
\hline
\end{tabular}

Keterangan:

$\mathrm{SD}=$ Standar Deviasi

Berdasarkan hasil analisis statistik deskriptif pada Tabel 3 menunjukkan bahwa terdapat peningkatan skor rata-rata prestasi belajar sebelum treatment dengan setelah treatment pada kelompok problem solving setting TAI terdapat peningkatan sebesar 38,72, sedangkan pada kelompok guided inquiry setting TAI 40,5

Tabel 4. Deskripsi Data Kemampuan Berpikir Kritis

\begin{tabular}{ccccc}
\hline \multirow{2}{*}{ Deskripsi } & \multicolumn{2}{c}{ PS Setting TAI } & \multicolumn{2}{c}{ GI Seting TAI } \\
\cline { 2 - 5 } & Pre & Post & Pre & Post \\
\hline Rerata & 34,38 & 72,74 & 35,06 & 75,94 \\
Max & 57,00 & 84,00 & 59,00 & 88,00 \\
Min & 19,00 & 64,00 & 15,00 & 68,00 \\
SD & 8,92 & 4,81 & 10,45 & 4,46 \\
Variansi & 79,58 & 23,17 & 109,25 & 19,87 \\
\hline
\end{tabular}

Berdasarkan hasil analisis statistik deskriptif pada Tabel 4 menunjukkan bahwa terdapat peningkatan skor rata-rata kemampuan berpikir kritis sebelum treatment dengan setelah treatment pada kelompok problem solving setting TAI terdapat peningkatan sebesar 38,86 , sedangkan pada kelompok guided inquiry setting TAI 40,88.

Tabel 5. Deskripsi Data Kedisiplinan Diri Siswa

\begin{tabular}{ccccc}
\hline \multirow{2}{*}{ Deskripsi } & \multicolumn{2}{c}{ PS Setting TAI } & \multicolumn{2}{c}{ GI Seting TAI } \\
\cline { 2 - 5 } & Pre & Post & Pre & Post \\
\hline Rerata & 99,74 & 111,06 & 98,79 & 116,61 \\
Max & 106 & 127 & 103 & 132 \\
Min & 91 & 101 & 88 & 104 \\
SD & 3,69 & 6,09 & 3,18 & 5,86 \\
Variansi & 13,59 & 37,15 & 10,11 & 34,37 \\
\hline
\end{tabular}

Berdasarkan hasil analisis statistik deskriptif pada Tabel 5 menunjukkan bahwa pada kelompok problem solving setting TAI, terdapat peningkatan skor rata-rata kedisiplinan diri siswa sebelum treatment dengan setelah treatment sebesar 11,32, sedangkan pada kelompok guided inquiry setting TAI 17,82.

Data penelitian ini selanjutnya di analisis untuk mengetahui keefektifan dari masingmasing pendekatan pembelajaran ditinjau dari 
prestasi belajar, kemampuan berpikir kritis, dan kedisiplinan diri. Analisis keefektifan ini menggunakan uji one sample t-test. Sedangkan untuk mengetahui perbandingan keefektifan dari masing-masing kelompok eksperimen akan dilakukan uji univariat dengan kriteria Bonferroni pada taraf 5\%. Sebelum dilakukan uji one sample t-test dan uji univariat dengan kriteria Bonferronimaka terlebih dahulu dilakukan uji MANOVA dengan melihat nilai signifikansi $T^{2}$ Hotelling'smaka pemenuhan asumsi-asumsi multivariat perlu dilakukan. Berikut hasil analisis pemenuhan asumsi normalitas dan homogenitas multivariat baik sebelum maupun setelah treatment ditunjukkan pada Tabel 5 dan Tabel 6 .

Tabel 5. Hasil Uji Normalitas Multivariat

\begin{tabular}{ccc}
\hline Kelas & $\begin{array}{c}\boldsymbol{d}_{\boldsymbol{i}}^{\mathbf{2}} \text { Sebelum } \\
\text { Treatment }\end{array}$ & $\begin{array}{c}\boldsymbol{d}_{\boldsymbol{i}}^{\mathbf{2}} \text { Setelah } \\
\text { Treatment }\end{array}$ \\
\hline PS Setting TAI & $50 \%$ & $55,88 \%$ \\
GI Setting TAI & $54,55 \%$ & $48,48 \%$ \\
\hline
\end{tabular}

Tabel 6. Hasil Uji Homogenitas

Matriks Varian-Kovarian

\begin{tabular}{lcc}
\hline & $\begin{array}{c}\text { Sebelum } \\
\text { Treatment }\end{array}$ & $\begin{array}{c}\text { Setelah P } \\
\text { Treatment }\end{array}$ \\
\hline Box's M & 7,822 & 12,872 \\
F & 1,238 & 2,038 \\
Sig. & 0,283 & 0,057 \\
\hline
\end{tabular}

Hasil analisis menunjukkan bahwa semua data baik sebelum maupun setelah treatment berdistribusi normal dan memenuhi asumsi homogenitas matriks-kovarians.Oleh karena kedua asumsi terpenuhi maka uji MANOVA dan uji univariat dapat dilakukan.

Selanjutnya dilakukan uji MANOVA untuk mengetahui perbedaan mean masingmasing kelompok baik sebelum maupun setelah treatment dengan melihat kriteria $T^{2}$ Hotelling's. Berikut data hasil uji MANOVA baik sebelum maupun setelah treatment yang ditunjukkan pada Tabel 7.

Tabel 7. Hasil MANOVA ( $T^{2}$ Hotelling's)

\begin{tabular}{lcc}
\hline \multicolumn{1}{c}{ Kelas } & $\boldsymbol{F}$ & Sig. \\
\hline Sebelum Treatment & 0,676 & 0,570 \\
Setelah Treatment & 4,686 & 0,005 \\
\hline
\end{tabular}

Berdasarkan hasil uji MANOVA sebelum treatment menunjukkan angka signifikansi lebih besar dari $0,05(0,570>0,05)$ maka hal ini menunjukkan bahwa kedua kelompok eksperimen memiliki mean kelompok yang sama artinya sebelum penelitian dilakukan peneliti telah memastikan bahwa kedua kelompok berasal dari mean yang sama secara multivariat $\left(\mathrm{H}_{0}\right.$ diterima atautidak terdapat perbedaan kemampuan awal antara kelas problem solving setting TAIdengan kelas guided inquiry setting TAIditinjau dari aspek prestasi belajar, kemampuan berpikir kritis, dan kedisiplinan diri siswa). Sedangkan hasil uji MANOVA setelah perlakuan menunjukkan bahwa angka signifikansi yang lebih kecil dari $0,05(0,005<0,05)$ maka hal ini menunjukkan bahwa setelah treatment kedua kelompok terdapat perbedaan mean multivariate $\left(\mathrm{H}_{0}\right.$ ditolak atauterdapat perbedaan keefektifan problem solving setting TAI dengan guided inquiry setting TAI ditinjau dari aspek prestasi belajar, kemampuan berpikir kritis, dan kedisiplinan diri siswa) artinya bahwa setelah diberikan perlakuan kedua kelompok tersebut menunjukkan adanya perbedaan keefektifan dari masing-masing kelompok eksperimen terhadap prestasi belajar, kemampuan berpikir kritis, dan kedisiplinan diri siswa. Untuk mengetahui keefektifan masingmasing kelompok eksperimen maka akan dilakukan uji one sample t-test sedangkan untuk mengetahui perbandingan keefektifan kelompok eksperimen ditinjau dari prestasi belajar, kemampuan berpikir kritis, dan kedisiplinan diri siswa maka dilakukan uji Bonferroni. Adapun hasil one sample t-test dan uji Bonferroni akan disajikan berturut-turut dalam Tabel 8 , Tabel 9, dan Tabel 10.

Tabel 8. Uji keefektifan

\begin{tabular}{lcc}
\hline \multicolumn{1}{c}{ PS Setting TAI } & $\boldsymbol{t}$ & Sig. \\
\hline Prestasi Belajar Matematika & 4,870 & 0,000 \\
Kemampuan Berpikir Kritis & 2,102 & 0,0215 \\
Kedisiplinan Diri & 10,580 & 0,000 \\
\hline
\end{tabular}

Tabel 9. Uji keefektifan

\begin{tabular}{lcc}
\hline \multicolumn{1}{c}{ GI Setting TAI } & $\boldsymbol{t}$ & Sig. \\
\hline Prestasi Belajar Matematika & 7,441 & 0,000 \\
Kemampuan Berpikir Kritis & 6,365 & 0,000 \\
Kedisiplinan Diri & 16,271 & 0,000 \\
\hline
\end{tabular}

Berdasarkan Tabel 8 dan Tebal 9 diketahui bahwa problem solving setting TAI dan guided inquiry setting TAI ditinjau dari prestasi belajar, kemampuan berpikir kritis, dan kedisiplinan diri siswa masing-masing memiliki nilai signifikansi sebesar 0,000 dan 0,000 untuk prestasi belajar, 0,0215 dan 0,000 untuk kemampuan berpikir kritis dan kedisiplinan diri siswa sebesar 0,000 dan 0,000. Nilai signifikansi untuk ketiga aspek tersebut masing-masing lebih kecil dari 0,05 sehingga dapat disimpulkan bahwa problem solving setting TAI dan guided inquiry setting TAI efektif ditinjau dari prestasi belajar, 


\section{Jurnal Riset Pendidikan Matematika, 3 (2), November 2016 - 230}

Hesti Setianingsih

kemampuan berpikir kritis, dan kedisiplinan diri siswa.

Hal tersebut sejalan dengan kajian teori yang mengungkapkan bahwa pendekatan problem solvingsetting TAI diharapkan efektif ditinjau dari aspek prestasi belajar matematika siswa. Pada pendekatan problem solving setting TAI sesama anggota dalam satu kelompok saling membantu untuk menyelesaikan masalah-masalah yang diberikan sehingga berimbas masalah lebih mudah untuk diselesaikan dan siswa dapat mempelajari konsep dengan lebih baik. Hal ini pun sesuai dengan pendapat Wray (2010, p.45) yang mengungkapkan bahwa pengetahuan yang dibangun oleh pikiran sendiri berdasar kenyataan dan pengalaman yang diperoleh akan lebih mudah diterima dan relatif membekas lebih lama dalam pikiran. Begitu pula dengan pendapat Vygotsky (Slavin, 2008, p.45) yang mengungkapkan bahwa siswa akan belajar dengan baik jika berada pada Zone of Proximal Development, siswa menghadapi masalah yang tidak bisa ia selesaikan sendiri, tetapi ia dapat menyelesaikannya melalui bantuan orang lain

Untuk aspek kemampuan berpikir kritis siswa, problem solving memiliki karakteristik menyajikan masalah pada siswa. Siswa akan tertarik dengan pembelajaran yang diawali dengan masalah yang terkait dengan materi yang dipelajari. Selain itu, setting TAI dalam proses memecahkan masalah juga memberikan kesempatan siswa untuk belajar secara individu. Hal ini memberikan kesempatan lebih banyak bagi siswa untuk belajar sesuai dengan kemampuan dan menggunakan cara mereka sendiri sehingga ketika siswa mengalami kesulitan, maka hal tersebut dapat mereka diskusikan dan selesaikan bersama dengan teman sekelompoknya.Hal tersebut pun sesuai dengan pendapat Trilling \& Fadel (2009, p.53) yang mengungkapkan bahwa keterampilan berpikir kritis dan pemecahan masalah dapat dipelajari melalui berbagai penyelidikan dan kegiatan pemecahan masalah.

Berkaitan dengan kedisiplinan diri siswa, problem solving memiliki karakteristik menyajikan masalah pada siswa. Pada penelitian dalam proses pembelajaran dengan pendekatan problem solving, siswa terlibat langsung dari awal pembelajaran sampai dengan akhir pembelajaran, baik dalam memahami masalah, maupun dalam menemukan konsep yang terkandung dalam penyelesaian masalah. Ketika siswa berhasil menyelesaikan masalah akan berdampak pada sikap positif siswa terhadap pembelajaran. Siswa yang memiliki sikap positif terhadap pem- belajaran akan sungguh-sungguh dalam belajar, aktif dalam diskusi, dan menyelesaikan tugas tepat waktu sehingga berimbas pada kedisiplinan diri siswa. Selain itu, adanya penghargaan dalam pendekatan problem solving setting TAI membuat siswa lebih bertanggung jawab dalam mencapai kesuksesan kelompoknya, sebab penghargaan kelompok diberikan sebagai penghargaan atas usaha bersama semua anggota dalam satu kelompok. Hal ini membuat setiap siswa lebih bertanggung jawab dalam mencapai kesuksesan.

Selanjutnya, dalam kaitannya pende-katan guided inquiry setting TAI efektif ditinjau dari prestasi belajar bahwa setelah siswa melakukan penyelidikan dan menemukan apa yang dicari kemudian dilanjutkan dengan memeriksa apakah hasilnya benar dengan menyelesaikan soal atau masalah sehingga menjadikan materi lebih bermakna. Selain itu dalam satu kelompok, siswa saling membantu dalam menyelesaikan masalah sehingga siswa akan belajar lebih baik. Pembelajaran dengan pendekatan guided inquiry juga memberikan stimulus pada minat dan keinginan siswa untuk memecahkan masalah dengan kemampuan yang mereka miliki karena mereka terlibat langsung dalam penyelidikan. Pengetahuan yang dibangun oleh pikiran sendiri akan lebih mudah diterima dan membekas lebih lama dalam pikiran sebagaimana pendapat Wray.

Untuk aspek kemampuan berpikir kritis siswa, guided inquiry memiliki karakteristik menyajikan masalah pada siswa untuk diselidiki.Siswa lebih dilatih untuk berpikir dan bernalar dalam menyelesaikan soal-soal atau masalah matematika. Selain itu dengan guided inquiry juga menumbuhkan dan menanamkan sikap inkuiri, salah satunya adalah curiosity. Adanya curiosity diwujudkan dengan selalu bertanya tentang berbagai hal, kemudian direalisasikan dengan mencari informasi sebanyakbanyaknya dengan bertanya kepada siapa saja yang diperkirakan mengetahui atau membaca dari berbagai sumber. Melalui kegiatan tersebut siswa dilatih untuk kritis, yang akan berimbas pada kemampuan berpikir siswa apabila dilakukan terus menerus dalam jangka waktu relatif lama. Hal tersebut sejalan dengan pendapat Trilling \& Fadel yang mengungkapkan bahwa keterampilan berpikir kritis dan pemecahan masalah dapat dipelajari melalui berbagai penyelidikan dan kegiatan pemecahan masalah. Selain itu dengan guided inquiry, mendorong siswa membangun solusi kreatif dalam meme- 
cahkan masalah dan adanya setting TAI dalam proses penyelidikan juga memberikan kesempatan siswa untuk belajar secara individu, sesuai dengan kemampuan dan menggunakan cara mereka sendiri.

Selanjutnya untuk aspek kedisiplinan diri siswa, adanya penghargaan dalam pendekatan guided inquiry setting TAI membuat siswa lebih bertanggung jawab dalam mencapai kesuksesan kelompoknya. Penghargaan kelompok diberikan sebagai penghargaan atas usaha bersama semua anggota dalam satu kelompok sehingga membuat setiap siswa lebih bertanggung jawab dalam mencapai kesuksesan. Setelah timbul rasa tanggung jawab pada diri siswa, maka akan timbul pula dalam diri siswa disiplin dalam mengikuti pembelajaran. Hal tersebut sejalan dengan pendapat Trowbrideg \& Bybee (1986, p.183) bahwa pembelajaran guided inquiry selain membangun kemampuan kognitif juga membangun kemampuan afektif dalam hal ini membangun sikap salah satunya adalah tanggung jawab

Tabel 10. Uji Perbedaan Keefektifan

\begin{tabular}{lcc}
\hline \multicolumn{1}{c}{ Aspek } & $\boldsymbol{t}$-Benferroni & $\boldsymbol{t}_{\text {tabel }}$ \\
\hline Prestasi Belajar Matematika & 2,2451 & 2,1742 \\
Kemampuan Berpikir Kritis & 2,8247 & 2,1742 \\
Kedisiplinan Diri Siswa & 3,7950 & 2,1742 \\
\hline
\end{tabular}

Berdasarkan Tabel 10 menunjukkan bahwa pada perbandingan kelompok problem solving setting TAI dan guided inquiry setting TAI ditinjau dari prestasi belajar, kemampuan berpikir kritis, dan kedisiplinan diri siswa nilai $t$ Benferroni masing-masing 2,2451; 2,8247; 3,7950 lebih besar dari $\mathrm{t}_{\text {tabel }}=2,1742$ sehingga $\mathrm{H}_{0}$ ditolak. Dengan demikian dapat disimpulkan bahwa guided inquiry setting TAI lebih efektif daripada pendekatan problem solving setting TAI ditinjau dari prestasi belajar, kemampuan berpikir kritis, dan kedisiplinan diri siswa.

Hasil analisis yang menunjukkan bahwa pendekatan pembelajaran guided inquiry setting TAI lebih efektif daripada problem solving setting TAI. Hal ini karena siswa dalam pembelajaran dengan guided inquiry Setting TAIlebih banyak keterlibatannya dibandingkan dengan siswa dalam kelas problem solving setting TAI. Dalam pembelajaran dengan guided inquiry setting TAI, setelah siswa melakukan penyelidikan dan menemukan apa yang dicari kemudian dilanjutkan dengan memeriksa apakah hasilnya benar dengan menyelesaikan soal atau masalah sehingga menjadikan materi lebih bermakna. Selain itu, dalam pelaksanaan guided inquiry, guru memberikan pengarahan dan bimbingan kepada siswa dalam melakukan kegiatankegiatan sehingga siswa yang berkemampuan rendah tetap mampu mengikuti kegiatan-kegiatan yang sedang dilaksanakan dan siswa yang mempunyai kemampuan tinggi tidak mendominasi kegiatan. Hal ini akan membantu siswa dalam pengonstruksian pengetahuannya. Adanya tahapan memilah data, menganalisis dan mengevaluasi dalam pembelajaran guided inquiry membuat siswa lebih dilatih untuk berpikir dan bernalar dalam menyelesaikan soalsoal atau masalah, sehingga materi yang dipelajari lebih bermakna karena siswa terlibat dalam penyelidikan, mendukung kemampuan pemecahan masalah dan mendorong siswa kritis dalam membangun solusi kreatif dalam memecahkan masalah. Selanjutnya, pembelajaran dengan pendekatan guided inquiry setting TAI dapat menumbuhkan dan menanamkan sikap inkuiri, memberikan stimulus pada minat dan keinginan siswa untuk memecahkan masalah dengan kemampuan yang mereka miliki, serta meningkatkan keyakinan diri siswa. Hal tersebut berimbas pada sikap dan kedisiplinan siswa dalam pembelajaran.

\section{SIMPULAN}

Berdasarkan hasil penelitian dan pembahasan diperoleh simpulan sebagai berikut: (1) pendekatan pembelajaran problem solving setting TAIdan guided inquiry setting TAI efektif ditinjau dari prestasi belajar, kemampuan berpikir kritis, dan kedisiplinan diri; (2) pendekatan guided inquiry setting TAI lebih efektif daripada pendekatan problem solving setting TAI ditinjau dari prestasi belajar, kemampuan berpikir kritis, dan kedisiplinan diri.

\section{DAFTAR PUSTAKA}

Azwar, S. (2013).Tes prestasi: Fungsi dan pengukuran prestasi belajar. Yogyakarta: Pustaka Pelajar.

BNSP.(2010). Paradigma pendidikan nasional abad XXI. Jakarta: Badan Nasional Standar Pendidikan.

Bell, F. H (1978).Teaching and learning mathematics (in secondary schools) Dubuque, Lowa: William C. Brown CO.

Bilgin, I. (2009). The effects of guided inquiry instruction incorporating a cooperative learning approach on university students' achievement of acid and bases concepts and attitude toward guided inquiry 


\section{Jurnal Riset Pendidikan Matematika, 3 (2), November 2016 - 232}

Hesti Setianingsih

instruction [Versi electronik]. Journal of Scientific Research and Essay. 4(10), 1038-1046

Brownlie, F., et al. (2003). Enhanching learning: Report of the student achievement task force. British Columbia. Diambil pada tanggal 13 Agustus 2014, dari http://www.bced.gov.bc.ca/taskforce/achi eve_task_rep.pdf.

Dehyadegary, E., et al. (2012). Academic engagement as a mediator in relationships between emotional intelligence and academic achievement among adolescents in kerman-iran [Versi electronik].Journal of American Science, 8, 9, 823-832.

Gok \& Silay. (2010). The effects of problem solving strategies on students' achievement, attitude and motivation [Versi electronik]. Latin-American Journal of Physics Education, 1 4, 7-21.

Gordon, T. (1996).Mengajar anak berdisiplin diri di rumah dan di sekolah.(Terjemahan S. Suprayitna \& Amitya Kumara). Jakarta: Gramedia Pustaka Utama. (Buku asli diterbitkan 1989)

Happy, N., \& Widjajanti, D. (2014). Keefektifan PBL ditinjau dari kemampuan berpikir kritis dan kreatif matematis, serta selfesteem siswa SMP. Jurnal Riset Pendidikan Matematika, 1(1), 48-57. doi:http://dx.doi.org/10.21831/jrpm.v1i1. 2663

Haryani, D. (2012). Profil proses berpikir kritis siswa SMA dengan gaya kognitif field independen dan berjenis kelamin laki-laki dalam memecahkan masalah matematika. Prosiding SNMPM Universitas Sebelas Maret, 145-163.Haylock, D. \& Thangata, F. (2007).Keyconcept in teaching primary mathematics. Thousand Oaks, CA: SAGE Publication.

Herman, T. (2007). Pembelajaran berbasis masalah untuk meningkatkan kemampuan penalaran matematis siswa SMP. Cakrawala Pendidikan, XXVI, 1, 41-62.

Jalal, A. (2012). Keefektifan pembelajaran matematika dengan pendekatan pemecahan masalah model Polya ditinjau dari kemampuan penalaran, berpikir kritis, dan berpikir kreatif matematis pada siswa SMA N 5 Kota Ternate. Tesis magister, tidak diterbitkan, Universitas Negeri Yogyakarta, Yogyakarta.

Mustamil, H. (2012). Pengembangan perangkat pembelajaran multilevel dengan pendekatan problem solving untuk meningkatkan sikap dan prestasi belajar matematika siswa SMP pada materi lingkaran. Tesis magister, tidak diterbitkan, Universitas Negeri Yogyakarta, Yogyakarta.

Johnson, K.L (2003). Willpower: The secrets of self-discipline. California: Louis \& Ford Publishing.

Junaidi. (2012). Perbandingan pembelajaran matematika dengan pendekatan open ended dan problem solving ditinjau dari sikap siswa terhadap proses pembelajaran matematika dan kemampuan pemecahan masalah matematika di kelas X SMAN 1 Pringgarata Lombok Tengah tahun ajaran 2011/2012. Tesis Magister, tidak diterbitkan, Universitas Negeri Yogyakarta, Yogyakarta.

Kemendiknas. (2006). Peraturan Menteri Pendidikan Nasional Nomor 23 Tahun 2006, tentang Standar Kompetensi Lulusan.

Kirk, R.E. (1995). Experimental design: Procedures for the behavioral sciences. California: Brooks/Cole Publishing Company.

Kuhlthau, C.C., Maniotes, L.K., \& Caspari, A.K. (2007).Guided inquiry: learning in the 21st century. London: Libraries Unlimited.

Lovat, T., et al. (2011). Value pedagogy and student achievement: Contemporary research evidence. London: Springer Science+Business Media.

Markaban.(2006). Model penemuan terbimbing pada pembelajaran matematika SMK [Versi elektronik]. Yogyakarta: P4TK, Dinas Pendidikan Nasional.

Mayadiana, D. (2005). Pembelajaran dengan pendekatan diskursif untuk meningkatkan kemampuan berpikir kritis matematik mahasiswa calon guru sekolah dasar. Tesis magister, tidak diterbitkan, Universitas Pendidikan Indonesia, Bandung. 
McElmeel, S. L. (2002). Character education: A book guide for teachers, librarians, and parents. Greenwood village: Librries unlimited.

McKinley, J. (2010). Raising black students' achievement through culturally responsive teaching. Alexandria, VA: ASCD.

Muijs, D. \& Reinold, D. (2005). Effective teaching: Evidence practice $\left(2^{\text {nd }} e d.\right)$. London, UK: SAGE Publications.

Muslimin, Z.I. (2012). Prestasi belajar mahasiswa ditinjau dari jalur penerimaan mahasiswa baru, asal sekolah, dan skor tes potensi akademik. Jurnal Penelitian Psikologi, 3, 1, 381-393.

Polya, G. (1985). How to solve it: A new aspect of mathematical method. Princeton: Princenton University Press.

Priatna, N. (2003). Kemampuan penalaran dan pemahaman matematika siswa kelas III SLTP di Kota Bandung. Disertasi, tidak diterbitkan, Universitas Pendidikan Indonesia, Bandung.

Republik Indonesia.(2003). Undang-Undang RI Nomor 20, Tahun 2003, tentang Sistem Pendidikan Nasional.

Rudinow, J. \& Barry, V.E. (2011). Invitation to critical thinking. Belmont: Thomson
Wadsworth.

Savage, T.V., \& Savage, M.K. (2010). Successful classroom management and discipline: Teaching self control and responsibility. Thousand Oaks, CA. SAGE Publications, Inc.

Slavin, R.E. (2006). Educational psychologi: Theory, research, and practice. $\left(8^{\text {th }} e d\right)$. London: Pearson Education, Inc.

Stevens, J. P. (2009). Applied multivariate statistics for the social sciences. New York: Taylor \& Francis Group, LLC.

TIMSS \& PRILS. (2012). TIMSS 2011: International results in mathematics. TIMSS \& PIRLS International Study Center, Lynch School of Education, Boston College.

Trilling, B \& Fadel, C. (2009). $21^{\text {st }}$ century skills: Learning for life in our times. San Fransisco: Jossey Bass.

Trowbridge, L.W. \& Bybee, R. W. (1986).Becoming a secondary school science teacher ( ${ }^{\text {th }}$ ed.). Colombus, Ohio: Merrill Publishing Company.

Wray, D. (2010). Looking at learning. Dalam J. Arthur \& T. Cremin (Eds.), Learning to teach in the primary school $\left(2^{\text {nd }}\right.$ ed.) (pp.41-52). Madison Ave, NY: Routledge. 